\title{
'That Senescence Itself is an Illness': A Transitional Medical Concept of Age and Ageing in the Eighteenth Century
}

\author{
DANIEL SCHÄFER*
}

Senectus ipsa morbus est . . .: Jacob Hutter (1708-1768) used this provocative hypothesis to draw attention to his doctoral thesis of the same title which was published in 1732 at the University of Halle in Central Germany. Hutter was an otherwise practically unknown figure, who later worked in his native Transylvania as a doctor and pharmacist. His dissertation was reprinted that same year with the title also translated into German: 'That senescence itself is an illness' (Daß das Alter an und vor sich selbst eine Krankheit seye). ${ }^{1}$ How did Hutter arrive at this striking hypothesis? Did he develop it from his own ideas and possibly also from those of his contemporaries, or was this aphorism based on older bodies of thought within medicine?

The following analysis of Hutter's work in its cultural historical context will show that, around his time, as far as the discussion of old age as an illness was concerned, a long and complex tradition was nearing an end. This tradition can be traced back to ancient times. Surprisingly, the radical claim that old age constitutes an illness had first appeared, not in a medical text, but in a literary work. Hutter, along with other authors around $1700,{ }^{2}$ quoted a particular passage from the comedy Phormio by Terence, written about 161 BC. The old Chremes, when asked by his brother Demiphon what illness he was suffering from, replied, "Why do you ask? The illness is old age itself" ${ }^{3}$ Lucius Aenaeus Seneca lent further weight to this effective quotation by referring to old age as an incurable illness. ${ }^{4}$ This paper will demonstrate, however, that this topic had already been treated in a controversial way by the medical works

* PD Dr. med. Dr. phil. Daniel Schäfer, Institute of the History of Medicine and Medical Ethics, Universität zu Köln, Joseph-Stelzmann-Str. 9/ Gebäude 29, D-50931 Köln, Germany.

The author wishes to thank his colleagues Klaus Bergdolt and Axel Karenberg for their advice and assistance in preparing this study. Special thanks go to Sinéad Donohoe and Theo Jäger for assistance with style and the translation of technical terms.

\footnotetext{
${ }^{1}$ Jakob Hutter, Tractatio medica qua senectus ipsa morbus sistitur. Das ist: Daß das Alter an und vor sich selbst eine Kranckheit seye, Halle an der Saale, Jo. Christian Hilliger, 1732. The text had already appeared in May 1732 as a 'Dissertatio inauguralis medica' of the same title (without a German subtitle) with a preface by Hoffmann
}

and a congratulatory poem. This work has up to now received only one brief mention in the standard work of Grmek, probably just because of its striking title; see Mirko D Grmek, On ageing and old age: basic problems and historic aspects of gerontology and geriatrics, The Hague, W Junk, 1958, p. 6.

${ }^{2}$ Hutter, op. cit., note 1 above, ch. 2 , and notes 80-82 below.

${ }^{3}$ Publius Terentius Afer, Phormio, V 575: senectus ipsast morbu'.

${ }^{4}$ Senectus enim insanabilis morbus est; Lucius Annaeus Seneca, Ad Lucillum epistolae morales 108, 28, in Seneca, Werke, ed. François Préchac, transl. M Rosenbach, 5 vols, Darmstadt, Wissenschaftliche Buchgesellschaft, 1995, vol. 4, p. 652. See also Seneca's obituary of Bassus Aufidius, Epist. moral. 30, 1+2, ibid., vol. 3, p. 250. 
of the antique world, and that it was a subject of dispute among various trends within medicine in early modern times.

The assertion of an illness called "old age" has affected common concepts of old age and of the ageing process in one way or another, even up to the present day. The very combination "old and ill", frequently encountered in common idioms and stories, would seem to support this claim.

The aim of this article is, first, to provide a historical overview of this theme. This is followed by an analysis of Hutter's thesis and of the contemporary concepts of age and ageing in the context of adoption and progress, change and continuity. Finally, there is an account of how geriatrics emerged from a background of conflict between traditional viewpoints and practical possibilities. The interpretation is based on the following main questions:

How did the adoption of the ancient ideas come about and what was the significance of this in early modern times, apart from the use of quotations?

Did the classification of old age as an illness give it a new pathological dimension in medicine? What are the related concepts of illness and death? The discussion and rejection of a natural ageing process culminating in an assertion of "natural death" are of particular interest in this context. This idea is also concerned with the concept of nature and its principles, which is very significant for medicine.

Did such a concept of old age lead to the creation of a new area of medicine (i.e. geriatrics)? This could mean, for example, the emergence of the central idea that senescence, like many other illnesses, is to a certain extent avoidable and possibly even curable. The hypothesis of "old age" as an illness links up with the controversy about longevity and immortality and with the old question of whether life can be prolonged by medicine. ${ }^{5}$

Was the theory that old age was an illness the expression of a basically negative attitude towards old age in society (under the premise that illness also had negative connotations in those days)?

The study presents the views of some largely unknown students of such famous doctors as Friedrich Hoffmann and Herman Boerhaave. While these doctors said little on the subject, their students could devote themselves exclusively to the popular topic of gerontology in their theses. Their treatment of the topic had, of course, to conform to a given structure, which in turn permitted a reiteration of the views of their professors. The study also aims at filling a gap in the portrayal of historical ideas of old age around $1700 .^{6}$

\footnotetext{
${ }^{5}$ See Gerald J Gruman, $A$ history of ideas about the prolongation of life, Transactions of the American Philosophical Society, n.s. vol. 56, pt 9, Philadelphia, The American Philosophical Society, 1966.

${ }^{6}$ See J Steudel, 'Zur Geschichte der Lehre von den Greisenkrankheiten', Sudhoffs Archiv, 1942, 35: 2-27; Frederic D Zeman, 'Life's later years: studies in the medical history of old age', $J$. Mt. Sinai Hosp., 1944/45, 11-1950/51, 17, reprinted in G J Gruman (ed.), Roots of modern gerontology and geriatrics, New York, Arno Press, 1979;
}

Grmek, op. cit., note 1 above; Richard L Grant, 'Concepts of ageing: an historical review', Perspect. Biol. Med., 1963, 6: 443-78; Paul Lüth, Geschichte der Geriatrie, Stuttgart, Ferdinand Enke, 1965; Karl Müller, 'Die Entwicklung der Geriatrie im 18. Jahrhundert', MD thesis, ETH Zürich, 1966; Peter N Stearns, Old age in European society: the case of France, London, Croom Helm, 1977; idem (ed.), Old age in preindustrial society, New York and London, Holmes \& Meyer, 1982; Peter Borscheid, Geschichte des Alters, 16.-18. Jahrhundert, 


\section{The Influence of Classical Doctrines}

In contrast to the literary sources of the ancient world, which favoured equating old age with illness in a seemingly subjective way, ${ }^{7}$ the definition of old age usually offered by medicine in ancient times seemed to be a kind of balancing act between the ideas of illness and natural decline. As far back as the so called "Book of Vessels" ("Gefäßbuch") of the Ebers Papyrus, there was a pathological concept of old age, i.e. a suggestion that the weakness associated with senescence is caused by the action of pain-inducing substances on the heart. ${ }^{8}$ The Corpus Hippocraticum contained an account of various illnesses associated with old age, ${ }^{9}$ which were the subject of many general and specific analyses in early modern times. However, the Corpus made only a few references to two characteristics which comprise old age: a small amount of innate warmth (later referred to as calor innatus), and a cold and wet, or alternatively dry, mixture of the humours. ${ }^{10}$

Münster, F Coppenrath, 1987; Margaret Pelling and Richard M Smith (eds), Life, death, and the elderly: historical perspectives, London and New York, Routledge, 1991; David I Kertzer and Peter Laslett (eds), Aging in the past: demography, society, and old age, Berkeley and London, University of California Press, 1995; Paul Johnson and Pat Thane (eds), Old age from Antiquity to post-modernity, London and New York, Routledge, 1998; Pat Thane, Old age in English history: past experiences, present issues, Oxford University Press, 2000; Daniel Schäfer, Medizinische Konzepte zum Alter in der frühen Neuzeit (1500-1800), Habilitationsschrift, Cologne University, 2001.

${ }^{7}$ See notes 3 and 4 above. The tragedies of Sophocles and the comedies of Aristophanes may well have been literary models for this subject; see also Simon Byl, 'Le vieillard dans les comédies d'Aristophane', L'Antiquité Classique, 1977, 46: 52-73. Horace (Ode I, 25; Epode VIII), Juvenal (Satura X) and the elegies of Maximianus (see note 42), which date from the late ancient times, also bemoaned the horrors of senescence in a poetic way. An overview of the theme of old age in the literature of ancient times is to be found in the following works: George R Coffman, 'Old age from Horace to Chaucer: some literary affinities and adventures of an idea', Speculum, 1934, 9: 249-77, on pp. 249-53; Georges Minois, History of old age, Cambridge, Polity Press, 1989, pp. 47-53, 92-100; Umberto Mattioli (ed.), Senectus. La vecchiaia nel mondo classico, 2 vols, Bologna, Pàtron Editore, 1995.

${ }^{8}$ Ebers Papyrus $855 \mathrm{~m}$; see $\mathrm{H}$ von Deines and H Grapow and W Westendorf, Übersetzung der Medizinischen Texte, Grundriß der Medizin der Alten Ägypter IV/1, Berlin, Akademie Verlag, 1958 , p. 5.

${ }^{9}$ Aphorismoi III 31; Oeuvres complètes d'Hippocrate, ed. É Littré, 10 vols, Paris, Baillière, 1839-61, repr. Amsterdam, Hakkert, 1961, vol. 4, p. 500. In particular, the Corpus Hippocraticum mentioned that many complaints are age-related and the course that they take is described along with the diet recommended in each case; compare Aphorismoi I 14, ibid., vol. 4, p. 466; De victu I 33, ibid., vol. 6, pp. 510-12.

${ }^{10}$ See overview by Simon Byl, 'La vieillesse dans le Corpus hippocratique', in François Lasserre and Philippe Mudry (eds), Formes de pensée dans la Collection hippocratique, Geneva, Droz, 1983, pp. 89-95. For overviews of ancient geriatric medicine, see Steudel, op. cit., note 6 above, pp. 2-6; Grmek, op. cit., note 1 above, pp. 50-5; Hermann Orth, 'Diaita geronton-die Geriatrie der griechischen Antike', Centaurus, 1963, 8: 19-47; Lüth, op. cit., note 6 above, pp. 45-91; Stefan Eidam, 'De senectute: Eine medizinhistorische Studie', Med. thesis, Munich, Technical University, 1989, pp. 8-19. 


\section{Daniel Schäfer}

Although Aristotle dealt with the negative aspects of old age in detail, ${ }^{11}$ he mentioned only briefly the physiopathological aspects, which were considered to be partly responsible for the facial characteristics of old people. In his opinion, the word for "old age", géras, was etymologically related to the word for "earth", gé, and old age was thought to have the cold and dry qualities of earth. An "illness" (nósos), such as grey hair, was considered the result of a lack of warmth, something characteristic of old age. If it were possible to restore the health and strength of the person, a change would occur, i.e. the old person would regain his youth. In accordance with this line of reasoning, illness could be described as acquired old age, and old age as a natural illness. ${ }^{12}$ While in De generatione animalium Aristotle still stressed that old age was a natural phenomenon, in De caelo he explained weakness, phthisis and old age as states beyond nature (parà phýsin), but only in comparison with the nature of the imperishable celestial element (later called quinta essentia).${ }^{13}$ In his Parva naturalia Aristotle also distinguished between two types of death, one natural and age-related, the other violent; both of which occurred because the inner warmth was not receiving sufficient "nutrition", an idea later described as the lamp metaphor. In the case of a natural death, so much of the warmth had already been breathed out of the body that a minor complaint (páthëma) was enough to extinguish the rest like a small flame. A violent death (especially in the case of illness) was believed to be caused by a larger external "heat" source, for example, fever, which deprived the (life) flame of its nutrition. ${ }^{14}$

The aphorism of the natural illness "old age" was obviously proverbial in the Hellenistic region, otherwise Terence would not have taken it up in a comedy 150 years after Aristotle. The late Roman contemporaries of Galen were also familiar with this concept. It seems they frequently discussed the issue of whether old age should be regarded as being a condition inside, outside or beyond nature, and whether old age was an illness, a disposition which made one ill, or something similar. Galen regarded these questions as irrelevant. ${ }^{15}$ In his discourse on marasmus,

\footnotetext{
${ }^{11}$ Rhetoric II 13 (1389b-1390a); Aristotle, Works (Loeb Classical Library), 23 vols, Cambridge, MA, and London, Harvard University Press and William Heinemann, 1983-1995, vol. 22, pp. 250-254; Politics II 6, 17 (1270b-1271a), ibid., vol. 21, p. 142; Nicomachean Ethics IV 1, 37 (1121b) and VIII 6, 1 (1158a), ibid., vol. 19, pp. 200 and 472.

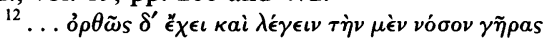

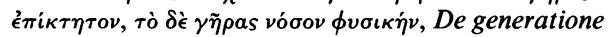
animalium V 4 (784b 33-34), Aristotle, op. cit., note 11 above, vol. 13, p. 530. This labelling of old age is also adopted by Clement of Alexandria, Stromata IV 6, 38, for example.

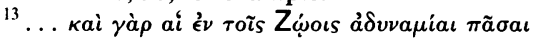

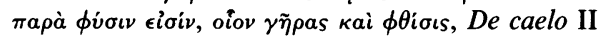
6 (288b 15-17), Aristotle, op. cit., note 11 above, vol. 6, p. 172 .
}

\footnotetext{
${ }^{14}$ On youth and old age IV and V (Parva naturala 469b), Aristotle, op. cit., note 11 above, vol. 8, pp. 422-4; On respiration XVII (Parva naturalia 478b-479a), ibid., vol. 8, pp. 470-4. See also On length and shortness of life V (Parva naturalia 466a + b; ibid., vol. 8, pp. 400-4), where the degenerative function of waste products is one of the topics discussed.

${ }^{15}$ De Sanitate tuenda I 5 and VI 2; Galen, Opera omnia, ed. C G Kühn, 20 vols, Leipzig, 1821-33, repr. Hildesheim, Georg Olms, 1964 65, vol. 6, pp. 20f., 387-8; idem, De marcore IV, ibid., vol. 7, pp. 680-1. For more information about Galen's ideas on old age, compare Simon Byl, 'La gérontologie de Galien', Hist. Philos. Life Sci., 1988, 10: 73-92.
} 


\section{'That Senescence Itself is an Illness'}

he therefore made fun of an unnamed contemporary sophist from Egypt ${ }^{16}$ who in a lost writing entitled Peri Agerasias (On avoiding senescence) extolled the possibility of eternal youth, on the basis that old age was nothing other than a treatable illness. Galen, who pointed out rather cruelly that the author was unable to treat himself, ${ }^{17}$ believed the ageing process was a more or less "natural" one because the decrease of the calor innatus made it unavoidable, ${ }^{18}$ although it could be slowed down, but not halted, by diet. In this way, Galen, who had an extensive knowledge of philosophy, referred directly to Aristotle, remaining faithful to his teaching despite the rather one-sided interpretation.

In fact, Galen concerned himself with the classification of ageing among the life processes possibly more than he himself wanted to admit. His approaches were various and sometimes contradictory. On the one hand, Galen divided the science of medicine into three basic groups: the study of that which is healthy, that which is ill, and that which is in-between (neutrum).$^{19} \mathrm{He}$ included old age in this last group and classified the health of the old person as being incomplete, due to his lack of vitality. He compared old people correspondingly to convalescents. ${ }^{20}$ Thus Galen's fifth book of dietetics, dealing almost exclusively with the care of the elderly (gërokomikón), not only provided the impetus for all subsequent "Gerocomies" ${ }^{21}$ but also expanded on the Aristotelian dyscrasia of old age (cold and dry) as a natural process (katà phýsin/secundum naturam). Like Aristotle, he described illness as being beyond nature (parà phýsin/praeter naturam). ${ }^{22}$ On the other hand, Galen also adopted the Aristotelian theory that old age was acquired as a result of an illness; comparing the insidious (cold) type of marasmus, which usually followed a consuming fever (i.e. an illness) and ended in death, ${ }^{23}$ to natural old age. Acute marasmus could also cause premature senescence (progeria) and this was described in ancient medicine with the technical term géras ek nósou/senium ex morbo (old age resulting from illness). ${ }^{24}$

\footnotetext{
${ }^{16}$ This is probably a reference to the sophist and physician Philippos, a student of Archigenes, who is also dealt with by Galen in De sanitate tuenda I, 12 and VI, 3; see Erich Beintker and Wilhelm Kahlenberg (transl.), Die Werke des Galenos, 5 vols, Stuttgart, Hippokrates-Verlag Marquardt, 1939, vol. 1, p. 48, n. 45; Byl, op. cit., note 15 above, p. 86 .

${ }^{17}$ De marcore II, Galen, op. cit., note 15 above, vol. 7, pp. 670-1.

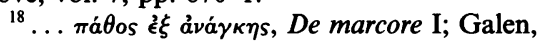
op. cit., note 15 above, vol. 7, p. 669.

${ }^{19}$ Ars medica 1; Galen, op. cit., note 15 above, vol. 1, p. 307. See note 35 below.

${ }^{20}$ De sanitate tuenda V 9 and VI 2; Galen, op. cit., note 15 above, vol. 6 , pp. 356, 389; compare the proverbial Latin translation from early modern times also used by Kühn: Senum sanitas querimoniis non vacat.

${ }^{21}$ The concept of gerocomy (care of the aged) was coined in De sanitate tuenda V 4; Galen, op. cit., note 15 above, vol. 6 , p. 330 . Regarding the
}

early-modern gerocomies, see notes 42 and 43 below, and Daniel Schäfer, 'Gerokomien - eine vergessene Fachlitatur der frühen Neuzeit', Würzburger Medizinhistorische Mittelungen, 2001, 20: 7-17.

${ }^{22}$ De sanitate tuenda I 5; Galen, op. cit., note 15 above, vol. 6, p. 21. See De symptomatum differentiis I; ibid., vol. 7, p. 47.

${ }^{23}$ De marcore IV and V; Galen, op. cit., note 15 above, vol. 7, pp. 677-87; De praesagiis ex pulsibus I, ibid., vol. 9, p. 247; Severus Iatrosophista, De instrumentis infusoriis seu clysteribus ad Timotheum, ed. F R Dietz (Med. thesis, Königsberg, 1836), p. 28.

${ }^{24}$ De marcore VIII (quoting Philippos, see note 16 above); Galen, op. cit., note 15 above, vol. 7, p. 700; the Latin term can be found in, for example, André du Laurens, $A$ discourse of the preservation of the sight, of melancholike diseases: of rheumes, and of old age, transl. Richard Surphlet, London, Felix Kingston, 1599, p. 174 . 


\section{Daniel Schäfer}

Late ancient texts about gerocomy, such as those of Paul of Aegina, ${ }^{25}$ are clearly based on Galen, although they do not discuss old age as an illness. The same evidently applied for the Islamic adoption. It should, however, be noted that the Byzantine Alexander of Tralles and the Arab Haly Abbas (in the translation of Constantinus Africanus) ${ }^{26}$ explained old age in the context of their fever theory as a natural variety of marasmus or phthisis: Alexander maintained that physicians should fight both old age and "real" marasmus, although both are incurable. But the greater the patient's suffering, the less treatment should be given, and those who suffered excessively should not be treated at all. Alexander's last recommendation, which probably applies only to the "real" and not the "natural" marasmus, was often presented as a proof in early modern times that old age was an incurable illness. ${ }^{27}$ Ibn Sina (Avicenna) considered ageing and death not to be a pathological entity, but rather a result of a natural decrease of the calor innatus due to the consumption of the humidum radicale.$^{28}$ Early Salernitan medicine had dealt in detail with practical aspects of geriatric dietetics. But the relevant sections of Galen's De sanitate tuenda (his gerocomy) were probably not available during this period and there was therefore no discussion of the physiopathological ideas that they contained. ${ }^{29}$ Not until the High Middle Ages did Western medicine also begin to accept Galen's evaluation of old age as a natural process. ${ }^{30}$ The anonymous author of De retardatione accidentium senectutis (often ascribed to Roger Bacon) in the thirteenth century shared Aristotle's belief that the ageing process, which causes hair to turn grey, for example, can in principle be reversed by diet or secret medication (occulta). ${ }^{31}$ However, he did not explicitly state that old age equalled illness, but cautiously suggested that if the same phenomena associated with old age (accidentia senectutis) were to occur in adolescence, they would be called illnesses. ${ }^{32}$ Bacon based his concept of two types

\footnotetext{
${ }^{25}$ Epitomae Medicae libri septem I 23; Paulos von Aegina des besten Arztes sieben Bücher, transl. I. Berendes, Leiden, 1914, pp. 23-4.

${ }^{26}$ See Michael McVaugh, 'The "humidum radicale" in thirteenth-century medicine', Traditio, 1974, 30: 259-83, on p. 261.

27 'About fevers' (Perì pyretõn) IV; Alexander von Tralles, Original text und Übersetzung, ed. T Puschmann, 2 vols, Vienna, W Braumüller, 1878, I, 369.

${ }^{28}$ Avicenna, Liber Canonis, lib. 1, fen.1, doctr. 3, cap. 3 (De complonibus [sic] etatum), Venice, 1507, repr. Hildesheim, Georg Olms, 1964, p. 4; regarding dietetics see also lib. 1 , fen. 3 , doctr. 3, cap. $1-6$, ibid., pp. $63^{\mathrm{v}}-64^{\mathrm{v}}$.

${ }^{29}$ Compare 'Flos medicinae Scholae Salerni', cap. 8, pars 4 and cap. 9, verses $1820-29$, in $S$ De Renzi (ed.), Collectio Salernitana, 5 vols, Naples, Filiatre-Sebezio, 1859; reprint Bologna, Forni, 1967, vol. 5, p. 52; see also Gerhard Baader, 'Die
}

Schule von Salerno', Medizinhist. J., 1978, 13: $124-45$.

${ }^{30}$ Regarding the acceptance of the corresponding papers of Galen by medicine in the late Middle Ages, see also Luke Demaitre, 'The care and extension of old age in medieval medicine', in Michael M Sheehan (ed.), Aging and the aged in medieval Europe, Toronto, Pontifical Institute of Mediaeval Studies, 1990, pp. 3-22, on pp. 4-5, 9; Luke Demaitre, 'The medical notion of "withering" from Galen to the fourteenth century: the treatise on marasmus by Bernard of Gordon', Traditio, 1992, 47: 259-307, on pp. 261-2.

${ }^{31}$ De generatione animalium V 4 (784 b 24-34); Aristotle, op. cit., note 11 above, vol. 13, pp. 528-9.

${ }^{32}$ Roger Bacon, De retardatione accidentium senectutis, ed. A G Little and E Withington, Oxford University Press, 1928, p. 19. 


\section{'That Senescence Itself is an Illness'}

of senescence ${ }^{33}$ in almost every way on the theory of Galen handed down by Avicenna. ${ }^{34}$ Scholastic medicine also discussed the status of old age repeatedly in its Quaestiones: Pietro Torrigiano de' Torrigiani (around 1300), a pupil of Taddeo Alderotti, for example, examined in detail (with implicit reference to Galen) whether the bodies of old people were neutra. ${ }^{35}$ An affirmative answer to this question meant a rejection of the equivalence of old age and illness. The Aristotelian lamp metaphor was also employed in Western medicine from the High Middle Ages until well into the seventeenth century for the idea of life-fuel that has run out; although usually in the context of marasmus and fever pathology. ${ }^{36}$

It is unlikely that Terence had already had an influence on medicine at this time. He had, however, been one of the ancient authors most widely read in the Middle Ages ${ }^{37}$ and his statement about "old age" being an illness was obviously known outside medicine; for instance, old age was described in late medieval texts of religious origin as being an illness of the natural body. ${ }^{38}$

By around 1500, at the latest, the illness "old age" had become a popular literary topos. This seems to have been due to both a certain hostility to senescence in this epoch $^{39}$ and the influence of humanism, which idealized authors of the ancient world such as Terence and Seneca. In a deliberate contrast to the idealization of old age in Cicero's Cato Maior De senectute, Erasmus of Rotterdam composed a poem for the Basle physician Guilielmus Copus about the burden of old age..$^{40}$ In his commentary to the book of Ecclesiastes, Martin Luther also stated as if it were self-evident: senectus enim per sese morbus est. Even Ambroise Paré, in his Introduction à la chirurgie,

\footnotetext{
${ }^{33}$ Uno modo ex naturali cursu nature, alio modo ex necessitatibus et curis pessimis; Bacon, op. cit., note 32 above, pp. 10-11. Compare also Roger Bacon, Opus maius ad Clementem Quartum, London, W Bowyer, 1732, pp. 466-72.

${ }^{34}$ See note 28 above.

${ }^{35}$ See Nancy Siraisi, Taddeo Alderotti and his pupils, Princeton University Press, 1981, p. 369. Around 1450, the chancellor of the University of Montpellier, Jacques Angeli, also discussed at around 1450 in his scholastic Puncta medicine (vol. 3, 3.16.1, in Sevelle Biblioteca Columbina manuscript 5-7-18, fol. $88^{\mathrm{vb}}$ ) the question of "whether old age is a illness" (quid senes sunt egri); see Demaitre, 'The care and extension of old age', op. cit, note 30 above, p. 9. Similar arguments are to be found in the late scholastic commentaries on Galen's Ars parva; see Timo Joutsivuo, Scholastic tradition and humanist innovation: the concept of Neutrum in Renaissance medicine, Helsinki, Academia Scientiarum Fennica, 1999, pp. 180-90.

${ }^{36}$ See Peter $\mathbf{H}$ Niebyl, 'Old age, fever, and the lamp metaphor', J. Hist. Med. Allied Sci., 1971, 26: 351-68, on pp. $359-68$.

${ }^{37}$ See C Villa, 'Terenz im Mittelalter und im Humanismus', in Lexikon des Mittelalters, 9 vols, Munich and Zürich, Artemis, 1980-99, vol. 8,
}

pp. 549-50. The quotation of Terence is also to be found in numerous handwritten texts from the Middle Ages; see Hans Walther (ed.), Proverbia sententiaeque latinitatis medii ac recentioris aevi, 9 vols, Göttingen, Vandenhoeck \& Ruprecht, 1963-86, vol. 4, p. 795, No. 28006.

${ }^{38}$ See Jacques Levebre, Libri commentariorum in epistolas Pauli, Paris, 1512 (unpaginated): senectus ... corporis naturalis morbus est, quod naturaliter in corruptionem tendet, verum non est morbus anime ...; quotation according to Rolf Sprandel, 'Alter und Todesfurcht in der spätmittelalterlichen Bibelexegese', in Herman Braet and Werner Verbeke (eds), Death in the Middle Ages, Leuven University Press, 1983, p. 113.

${ }^{39} \mathrm{Cf}$. Minois, op. cit., note 7 above, pp. 249-87.

${ }^{40}$ Terence or Seneca are indirectly quoted by Erasmus: teterrima porro senecta morbus ingens ...; Erasmus of Rotterdam, 'Carmen ad Guilielmum Copum Basileiensem de senectutis incommodis', in Lukian, De senectute, habes hic primum Luciani Samosateni Macrobios, hoc est longaevos, Vincentio Obsopoeo interprete ... Adj. Carmen Erasmi Roterodami de molestiis senuctutis [sic] ..., Nuremberg, 1537 (unpaginated). 


\section{Daniel Schäfer}

made a passing reference to old age as being a type of illness (un espèce de maladie) by its very nature. ${ }^{41}$

These polemic Renaissance statements clearly oppose the predominant medical theory as it was discussed in the earlier Quaestiones. Nevertheless, the now emerging specialist medical literature about old age was at first very uncontroversial. The physician Gabriele Zerbi (1445-1505), who practised in Padua, Bologna and Rome, dealt in detail with Galen's concept of gerocomy, explicitly using the same term. His work Gerontocomia, written in 1489 and dedicated to Pope Innocent VIII, was the first of numerous texts printed during the late Renaissance about old age. The paper compared natural death (as a result of the extinction of the calor innatus) to death caused by illness and contained only a short mention of old age as a "natural illness" (quoting Aristotle). ${ }^{42}$ This is not surprising, however. Gerocomies from Zerbi to Floyer tended to be considerably more concerned with practical aspects such as care and dietetics of the elderly, and conservation and prolongation of life, than with theoretical concepts. ${ }^{43}$

In the sixteenth century, humanistic ideas were being increasingly accepted by the medical profession. But medical texts were not involved in the debate about whether old age was, in fact, an illness until about 1600 . The three following examples show how intensively the medical-academic world of the seventeenth century, until shortly before Hutter, discussed this equivalence by adopting and varying several theories of the antique world.

Aurelio Anselmi, a doctor practising in Mantua maintained, for example, in a special chapter on this topic in his comprehensive Gerocomica (1606) that age was not an illness but a natural process. This was a direct response to the views of Terence, whom he mentioned by name, and other ancient comici ${ }^{44} \mathrm{He}$ claimed that what the comedy tried to show about human affairs was actually a contradiction of nature and her continual process of death and rebirth. Like Aristotle, Anselmi recognized old age as corruptio (at best without external illness). Analogous to generatio, it is a law of nature for every living being, while illness, on the other hand, goes beyond or even against nature. ${ }^{45}$ The Hippocratic aphorism that old people were less ill than young people was another important argument for Anselmi. This

\footnotetext{
${ }^{41}$ Martin Luther, 'Annotationes in ecclesiasten Salomonis', in idem, Exegetica opera latina, ed. Christoph Stephan Gottlieb Elsperger and Heinrich Schmidt, 28 vols, Erlangen, Caroli Heyderi, 1829-86, vol. 21, p. 236. Ambroise Paré, 'Introduction a la chirurgie', cap. 14, in idem, Ć́uvres complètes, 3 vols, Paris, J-B Baillière, $1840-41$, vol. 1, p. 66.

${ }^{42}$ See Gabriele Zerbi, Gerontocomia: on the care of the aged, and Maxmianus [sic], Elegies on old age and love, transl. L R Lind, Philadelphia, American Philosophical Society, 1988, pp. 35-6.

${ }^{43}$ See Gilbert Philaretes [Fuchs], Gerocomice, hoc est, senes rite educandi modus \& ratio, Cologne, Martin Gymnich, 1545; Antonio Fumanelli, 'De senum regimine commentarius', in idem, Opera multa ac varia, cum ad tuendam
}

sanitatem, tum ad profligandos morbos plurimum conducentia, Zurich, Andreas Gesner, 1557, pp. 1-89; Aurelio Anselmi, Gerocomica. Sive de senum regimine opus, Venice, Francesco Ciotti, 1606; François Ranchin, 'THROKOMIKH-De senum conservatione \& senilium Morborum Curatione', in idem, Opuscula medica, Lyons, Pierre Rabaud, 1627, pp. 456-592; Bernardinus Stainer, Gerocomicon sive Diaeteticum Regimen de conservanda senum sanitate ..., Würzburg, Elias Michael Zinck, 1631; John Floyer, Medicina gerocomica: or, the Galenic art of preserving old men's healths, London, J Isted, 1724.

${ }^{44}$ Anselmi, op. cit., note 43 above, p. 21 ; see also cap. 8 Num senectus sit morbus, ibid., pp. 50-6.

${ }^{45}$ Morbus praeter naturam vel potius contra naturam; ibid., p. 52. 


\section{'That Senescence Itself is an Illness'}

would not be the case if old age were an illness. ${ }^{46}$ Of course, the health of the old person was not considered to be a fixed condition, but it could be maintained by leading a certain lifestyle, which had almost the consequence of a medical art form. Anselmi's traditional position had a direct influence on the similar standpoint of the Pope's physician, Paolo Zacchia, on this issue. ${ }^{47}$

Deviating slightly from rigid Galenic theory, the professor and chancellor of the University of Montpellier, François Ranchin (1565-1641), described in his Gerokomike (1627) the third and last stage of old age (aetas decrepta) as "natural senescence", classifying this, however, as a general illness of old age (like cachexia or pruritus). Using Galen's analogy of old age and "cold" marasmus, he distinguished between this and "accidental senescence", which he called "old age resulting from illness", ${ }^{48}$ according to the two groups which ancient medicine had expressly separated. Ranchin devoted considerable attention to the analysis of the status of the old person in terms of lifestyle and discussed various models proposed by Galen in an effort to free his source from the accusation of inconsistency. On the one hand, old age was to be seen as a natural process that brought about natural changes. Old people should therefore be considered to be healthy. On the other hand, they should be regarded as being frail (debilis), because of the restrictions imposed on the senses, the typical weakness of the main parts of the body, and the drying out of the whole body. But this condition did not have the concrete effects of an illness. ${ }^{49}$ According to Ranchin, old age was analogously (per analogiam) considered to have a neutral status between illness and health. This did not mean, as some people thought, ${ }^{50}$ that old age should be seen as a decline in the sense of being an illness, but rather an illness-prone state that led towards death. Although the ageing process was thought to be unstoppable, Ranchin described a popular tendency to treat old people as convalescents, as Galen had done, although a complete restoration of health was not to be hoped for. Therefore, he also recommended that they follow a certain diet according to the Theory of Opposites (contraria contrariis), which really applied only to ill people; old people clearly moved away from a natural and vital condition. ${ }^{51}$

In a disputation with Georg Hieronymus Welsch (1645), the Strasbourg professor and staunch Galenist, Melchior Sebitz Jr (also Sebizius or Sebisch; 1578-1674) argued in a considerably more conventional and defensive manner than Ranchin. In addition to the three chronological stages of natural old age mentioned by Galen in De sanitate tuenda, Sebitz and Welsch also identified three further accidental forms, which resulted from premature loss of body heat and drying by fever (marasmus), by cooling therapy for fever or by too much activity. ${ }^{52}$ They described

\footnotetext{
${ }^{46}$ Ibid., p. 22; cf. Aph. 2, 39, Hippocrates, op. cit., note 9 above, vol. 4 , p. 480.

${ }^{47}$ Paolo Zacchia, Quaestiones medico-legales, 4 vols, Leipzig, Rehefeld, 1630, vol. 1, tit. 1, q. 9, pp. $77-81$.

${ }^{48}$ Haec senium ex morbo appellatur; Ranchin, op. cit., note 43 above, p. 459.

${ }^{49}$ Deficiant opera, ut in morbis; ibid., pp. 541-2 (An senectus morbus senilis dici debeat).

${ }^{50} \mathrm{Ibid}$. It is not clear whether Ranchin is referring to authors of ancient times (the sophists
}

from Galen's De marcore IV, mentioned ibid., p. 541) or to contemporaries; see note 60 below.

${ }^{51}$ Ranchin, op. cit., note 43 above, pp. 459 , 465-6.

${ }^{52}$ Disputatio de senectutis et senum statu ac conditione: Solennis exercitii gratia in alma Argentoratensium Universitate proposita à Melchiore Sebizio ... Respondente Georgio Hieronymo Welsch, Strasbourg, Eberhard Welper, 1645, th. XLIII and XLIV (unpaginated). 


\section{Daniel Schäfer}

only these forms as illness (plane morbosam). However, Hippocrates and others (alii) would have classified all old persons as being ill (morbosos) and old age as an illness. ${ }^{53}$ Sebitz and Welsch considered this definition of illness to be very broad as it included any sort of weak physical constitution. ${ }^{54}$ They, on the other hand, believed that an illness had to have such a restrictive effect on the bodily functions that medical intervention was required. This did not apply to old age and, therefore, the constitution of old persons rendered them more susceptible to illness than the young. ${ }^{55}$

These three examples show how various arguments were used in the seventeenth century to discuss and cautiously reject the theory that old age and illness were the same thing. ${ }^{56}$ The most graphic account of this contemporary idea of the pathology of old age (see Figure 1) is given by the French doctor and writer, François de Fougerolles (1560-1620). He drew up a comparatively simple plan demonstrating the influence of the Aristotelian psychology of old age and the efforts of medicine, which was still strongly influenced by Galen, to find the balance between old age as a "natural illness" and the traditional illnesses of old age. ${ }^{57}$

\section{Old Age as an Illness in the Framework of Iatromechanical Concepts}

Not only the defensive position of Sebitz and Welsch, but also the resolute rejection of the "incorrect hypothesis that old age is in itself an illness" by the town physician of the city of Ulm, Augustin Thoner (1567-1677), implied that conflicting voices were already being heard within medicine around this time ${ }^{58}$ It is especially significant that Santorio Santorio, honoured by the later iatromechanics as their forerunner, in his famous aphorisms De medicina statica (1614) referred to old age as an illness

\footnotetext{
${ }^{53}$ Here (th. LXIII, unpaginated) Sebitz and Welsch are apparently referring (with regard to the first half of the sentence) to an already quoted passage from the Corpus Hippocraticum (De victu $\mathrm{I}, 32$ ), which from the context really applies only to people with a cold and moist

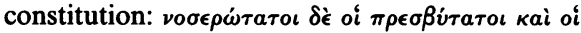
єै $\gamma \gamma \iota \sigma \tau \alpha$; Hippocrates, op. cit., note 9 above, vol. 6, p. 508. It is impossible to establish whether the second part of the quotation is contained in the Corpus Hippocraticum, and it is probably meant for alii (perhaps Terence, earlier mentioned in th. LIII, or the sophists from Galen's De marcore IV, mentioned in th. LVI). This lack of clarity in Welsch and Sebitz's text could be the cause of the error which is also to be observed in the work of Friedrich Hoffmann (see note 79 below).

${ }^{54}$ On the contrary, Robert Le Secq and Joannes Bonier (Quaestio medica An senibus exercitatio? Paris, 1627, unpaginated) work from a broad definition of health, emphasizing that senectus non est morbus; similarly Joannes Mandat and Lancelotus De Frade, Quaestio medica An mel senibus?, Paris, 1630 (unpaginated).
}

\footnotetext{
${ }^{55}$ Sebitz and Welsch, op. cit., note 52 above, th. XLI-LIII (unpaginated).

${ }^{56}$ The Terence quotation is also mentioned in passing in juridical dissertations and theological tracts of the seventeenth century: Friedrich Deckherr and Georg Lessius, EMTA $\Sigma$ quaestionum de jure senectutis, Strasbourg, Josias Stadel, 1642, Quaestio V (unpaginated); Johannes Rebhan and Johannes Paulus Ebner, De jure senum senectutisque privilegiis, Strasbourg, Georg Andreas Dolhopff, 1663, p. 6; Benedictus de Bacquere, Senum medicus, quaedam praescribens observanda, ut sine magnis molestiis aliquousque Senectus protrahatur, Cologne, Heirs of J Widenfeldt, 1673, p. 246.

${ }^{57}$ François de Fougerolles, De senum affectibus praecavendis nonnullisque curandis enarratio, Lyons, Ian. de Gabiano, and Laur. Durand, 1617, p. 53.

${ }^{58}$ Augustin Thoner, Observationum medicinalium, haud trivialium, Libri 4 [...] adjuncti sunt Consulationum cum diversarum regionum medicis habitarum, et Epistolarum de variis rebus medico-philosophicis, disserentium, Libri 2, Ulm, Gerlin, 1651, Epistola No. 4, p. 284.
} 


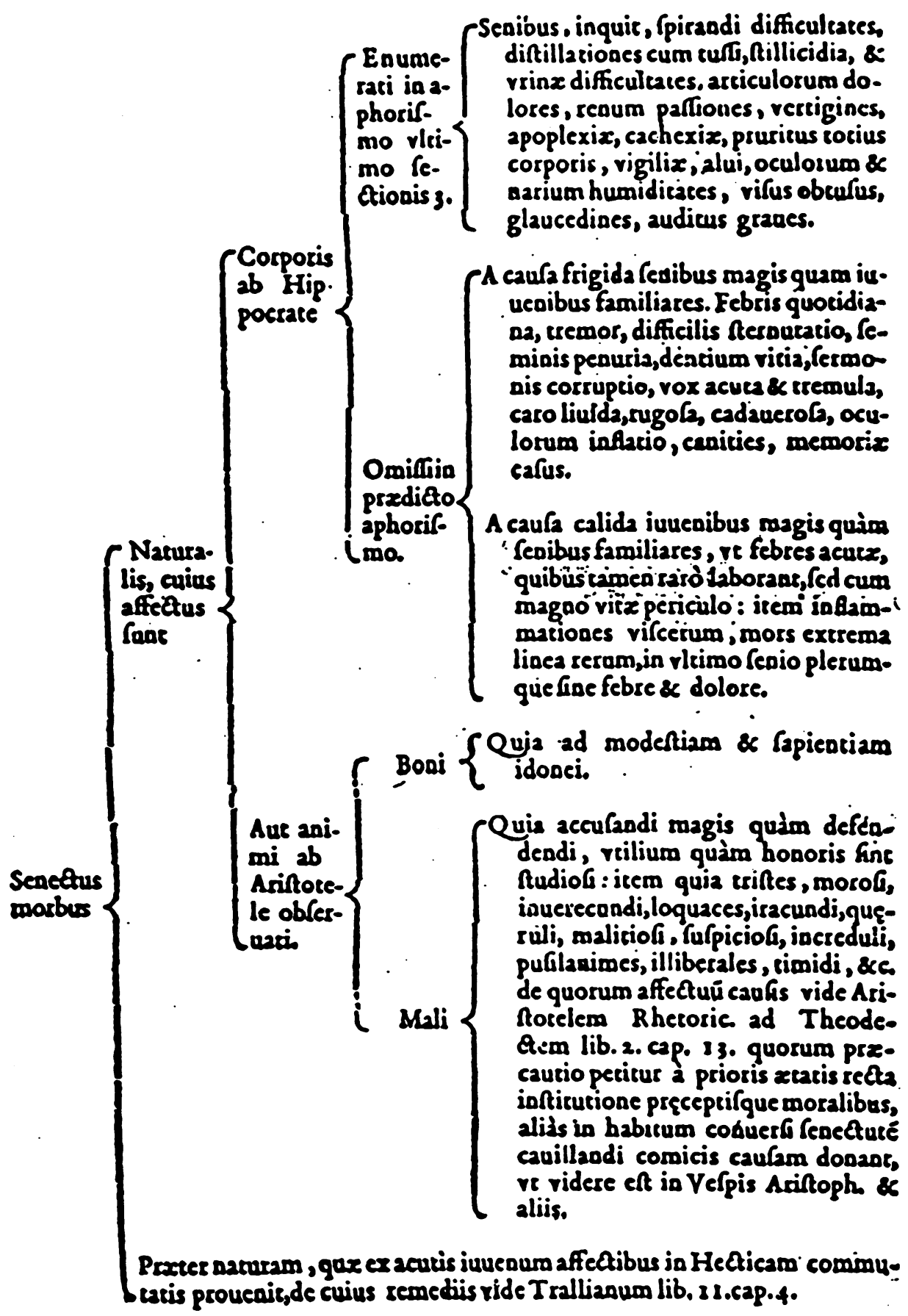

Figure 1: François de Fougerolles, De senum affectibus praecavendis nonnullisque curandis enarratio (Lyons, Ian. de Gabiano and Laur. Durand), 1617, p. 53. 


\section{Daniel Schäfer}

that ended in death because of the hardening of the fibres. ${ }^{59}$ From about 1650 , more and more works integrated the proverb of Terence with little reflection. ${ }^{60}$ Many contemporary papers included it in their introduction, which usually laid out a sweeping presentation of the disaster of old age. This is also the case in the dissertation of Friedrich Schrader and Johann Heinrich Blume (1699); although these authors disproved Terence at a later stage. But, instead of naming him, they maintained that Galen had incorrectly spoken of a natural illness (morbum naturalem) because the status of the old person was a natural one; for the actiones of the body were not as perceptibly and adversely affected as in the case of an illness - otherwise one would have to describe children in the same way. ${ }^{61}$ This refutation of old age as an illness, despite the predominance of (mainly iatrochemical) anti-Galenic basic pathophysiological concepts, is also indicative of both the decisive significance and the inconsistency of the definition of illness at around 1700. While Schrader, Blume and their contemporaries still traditionally (cf. Ranchin; Sebitz and Welsch) offered a relatively narrow definition of this concept, ${ }^{62}$ it was expanded on by others just some years later.

Some fifteen years before the dissertation of Jacob Hutter mentioned at the outset, the Terence quotation was directly presented as a medical hypothesis for the first time in a dissertation. Aegidius Glagau, a disciple of Boerhaave, postulated that old age and illness were one and the same thing in the very title of his dissertation written in Leiden in 1715. But his approach was a very general one. So he viewed things in a relativistic (and also holistic) way, as we can clearly see from this quotation, allegedly from Hippocrates, contained in the preface: "the entire person is ill from the moment of his birth" ${ }^{63}$ Glagau maintained that no age group had the privilege of lasting health. In a detailed introduction, he also stressed the natural

\footnotetext{
${ }^{59}$ Santorio Santorio, De medicina statica aphorismi, I 83, V 35, V 80; see Johann Timmii, Transpiratio Sanctoriana ... oder des berühmten Medici Sanctorii à Sanctorio Tractat von der unempfindlichen Ausdünstung aus dem Lateinischen ins Teutsche übersetzt ...., Bremen, Nathanael Saurmann, 1736, pp. 39, 165.

${ }^{60}$ Compare the comment from Bernardinus Stainer in connection with a quotation from Galen (De sanitate tuenda V): Uno verbo alibi senium vocat perpetuam aegritudinem; Stainer, op. cit., note 43 above, Dedicatio (unpaginated). Etienne Le Gaigneur and Charles Marteau (1663) argue in a more polemic way, maintaining that old age is only an illness among idle old people (otiosi), who are more prone to melancholic diseases. Ten years later, Caspar Posner and Justus Hermann Vultejus, in principle staunch Galenists, do not even criticize Terence in their reflections on the concept of a natural death brought on solely by the illness "old age"; Caspar Posner and Justus Hermann Vultejus, Diatribe academica de longaevitate hominum, Jena, Nisianus, 1673, $\S 5$ (unpaginated).

${ }^{61}$ Friedrich Schrader and Johann Heinrich Blume, Dissertatio medica inauguralis de senectutis
}

praesidiis, Helmstadt, Georg Wolfgang Hamm, 1699, $\$ 4$ and 10 (unpaginated).

${ }^{62}$ Like Schrader and Blume, Hermann Paul Juch and Johannes Gottfried Kamper also reject the Terence quotation with the objection that the application of the concept of illness is too broad (nimis latum eius vocis usum); Hermann Paul Juch and Johannes Gottfried Kamper, Dissertatio inauguralis medica de senectute, Erfurt, J C Hering, 1732, p. 20.

${ }^{63}$ Totum Hominem a Nativitate Morbum esse; Aegidius Glagau, Disputatio medica inauguralis de senectute ipsa morbo, Leiden, 19 September 1715 , Prooemium (unpaginated). The aphorism cannot be found in this form in the Corpus Hippocraticum. However other authors of the eighteenth century also attribute this quotation to Hippocrates: Michael Alberti and Johann Gottlieb Hoffmann, Dissertatio inauguralis medica, De dysuria senili, Halle an der Saale, Joh. Christian Hendel, 1728, p. 3. In another paper quoting this aphorism the authorship of Hippocrates is only hinted at: Georg Ernst Stahl and Johannes Conradus Michaelis, Dissertatio inauguralis medica, De senum affectibus, Halle an der Saale, Christian Henckel, 1710, p. 5. 
laws and limits which govern the disposition and growth of the human machina in the mother's womb, especially with regard to its vessels and their transformation into hard ligaments and membranes. These natural principles of human genesis corresponded to those of regression. Glagau maintained that once a person had reached the peak of his development (akmé), a progressive and unavoidable hardening, stiffening and narrowing of the vessels would take place. As a result, the heart would also weaken, the blood become viscous and stagnate in the periphery of the body. Many functions of the body, secretion in particular, would be disrupted because of this one etiology (ex uno hoc fonte), and the familiar complaints of old age (symptomata) could all be traced back to this hydraulic-mechanic failure-as a part of illness. Glagau also believed that, although medicine could alleviate the symptoms of old age, it could not cure this illness. ${ }^{64}$

Glagau's observations on old age are actually relatively underdeveloped compared to those in a second and certainly most important dissertation on the illness "old age" by Jacob Hutter. This work will now be treated to an in-depth analysis.

Hutter's medical thesis, like so many others of his time, is not original in any way. He uses very few sources, referring for the most part to the works of Professor Friedrich Hoffmann (1660-1742) from Halle. ${ }^{65}$ Hoffmann, who was renowned for both the mechanistic view in which he formulated his theories and for his pharmaceutical reform, was already an old man by 1732, and most probably Hutter's thesis supervisor. Hutter's tractatio has a rhetorically complex structure, and its detailed description of the pathological bases and systematic development of the topic make it especially suitable for the portrayal of possible theoretical bases of eighteenth-century "geriatrics".

\section{Introduction}

Hutter begins his discourse with the unexpected question of whether death is really necessary. He contrasts briefly and without comment the familiar answers provided by unspecified philosophers, ${ }^{66}$ by the medical theorist Johan Baptista van Helmont and his pupils (damage to the flame of life and to the inner warmth ${ }^{67}$ ) and by the pupil and successor of Georg Ernst Stahl in Halle, Michael Alberti (life movements

\footnotetext{
${ }^{64}$ Glagau op. cit., note 63 above, pp. 21-2.

${ }^{65}$ Regarding Hoffmann see notes 78 and 79 below; see also W U Eckart and C Gradmann (eds), Ärztelexikon, Munich, C H Beck, 1995, pp. 194-95. Both Hoffmann and Hutter appear in the literature indexes of Canstatt and Geist as the author of Hutter's Dissertatio of 1732: Carl Friedrich Canstatt, Die Krankheiten des höheren Alters und ihre Heilung, Erlangen, Ferdinand Enke, 1839, p. 6; Lorenz Geist, Klinik der Greisenkrankheiten, Erlangen, Ferdinand Enke, 1860, p. 15.

${ }^{66}$ Hutter mentioned only theological doctrines: the separation of soul and body; divine providence on account of the Fall of Man; Hutter, op. cit., note 1 above, pp. 5-6.
}

\footnotetext{
${ }^{67}$ Ibid. The theory of the inner warmth (calor innatus), which Hutter traced back to van Helmont and his students, is of course derived from both ancient and Islamic sources (see below). Van Helmont, however, rejected Galen's concept of a drying out of the moist nutrition of the flame; he applied this idea much more to the spiritus vitalis of the blood, which decomposes not as a result of drying out, but because of an overall decrease in vitality. See Niebyl, op. cit., note 36 above, pp. 365-6; Michael Stolberg, 'Die Lehre vom "calor innatus" im lateinischen Canon medicinae des Avicenna', Sudhoffs Archiv, 1993, 77: 33-53.
} 


\section{Daniel Schäfer}

of the soul become lethargic ${ }^{68}$ ) with the teaching of Hoffmann himself, who had, according to Hutter, used anatomical studies as a basis to prove the fundamental mortality of man, irrespective of such external factors as illness or violence. Hutter's intention is to use this basis for his examination of old age, which, he maintains, is a cause of death per se. He argues that for this reason it should be referred to as an illness from the outset (not just a proneness or susceptibility to illness), because it wears down a person's strength, disrupts the functions of his entire body and restricts movement, just like any other illness.

\section{Part I: Physiopathology of Old Age}

In the first part of the thesis, Hutter distinguishes between three types of afflictiones (impairments) of the body that are part of old age:

(1) Changes in the life-sustaining movements (motus vitales). This means, above all, circulatory disorders, which cause a loss of warmth and strength, and also a malfunctioning of the tensing and relaxing movement in all channels, as well as in peristalsis and muscle fibres.

(2) Malfunctioning of vegetative or physical functions (functiones naturales ${ }^{69}$ ), which manifests itself in a loss of appetite, digestive problems resulting from a decrease in secretion and excretion, a decrease in fertility, a gradual drying-out of the body, a hardening and thickening of the skin, and in sleep disorders, which prevent the regaining of strength.

(3) A decline in mental and emotional capacities (functiones animales) leading to a detrimental effect on sensory perception and also on the will, memory, intellect and powers of reasoning.

Like Seneca, whom he quotes at length by name at this point, ${ }^{70}$ Hutter suggests that the individual undergoes a continuous process of change which begins in youth and ends in old age. He searches for a rational scientific explanation, finding the answer for all three groups of disorders by comparing the physique of the old person with that of the healthy organism.

Hutter considers an assessment of the solid and liquid components of the body as well as of an unrestricted blood supply to all of its parts as a fundamental part of this comparison. According to him, physiology and mechanics had previously shown that the solid parts of the body (vessels, nerves, muscles and fibres) should

\footnotetext{
${ }^{68}$ Hutter, op. cit., note 1 above, p. 6. See Michael Alberti, Introductio in universam medicinam tam theoreticam quam practicam. Certis positionibus comprehensa, Halle an der Saale, Waisenhaus, 1718 , pp. 435-6. This idea is a reference to the animism of Georg Ernst Stahl, but using the iatromechanical terminology of the motus vitales (see below). The animistic concept does not however appear in an earlier dissertation supervised by Stahl and Michaelis, op. cit., note 63 above.

${ }^{69} \mathrm{Cf}$. Ingo Wilhelm Müller, Iatromechanische Therapie und ärztliche Praxis im Vergleich zur galenistischen Medizin: Friedrich Hoffmann-
}

Pieter van Foreest, Jan van Heurne, Stuttgart, Franz Steiner, 1991, pp. 161-2. This part of Hutter's thesis (op. cit., note 1 above, $\S 6$, p. 11) is also clearly influenced by the concept of the "six non-naturals"; cf. Wolfram Schmitt, 'Res non naturales', in Lexikon des Mittelalters, op. cit., note 37 above, vol. 7, pp. 751-2.

${ }^{70}$ Nemo nostrum idem est in senectute, qui fuit juvenis, nemo mane, qui pridie, corpora nostra rapiuntur fluminum mare ... corpus nostrum transit ad perfectionem, transit etiam rursus ad interitum; Seneca, Epistolae morales 58, 22, in: Seneca, op. cit., note 4 above, vol. 3, p. 480 . Cf. Hutter, op. cit., note 1 above, p. 12. 


\section{'That Senescence Itself is an Illness'}

be neither too hard nor too soft, in order to ensure an appropriate supply of blood and nerve fluids. ${ }^{71}$ Hutter's theory states that the progressive hardening of all fibres of the body, which is especially evident in the calcification of the aorta in the heart region, was a part of the ageing process. ${ }^{72} \mathrm{He}$ maintains that this process restricts the life-sustaining movements (motus vitales) as the result of an obstruction (supposedly mechanical in origin) of the blood supply. In view of the fact that all the organs of the body work together, he thinks that this also causes a disruption of the physical actions (actiones naturales) and of the intellectual and emotional capacities (actiones animales). In this way, for example, Hutter explains loss of appetite by the loss of strength of the stomach and by reduced secretion and excretion due to a blockage of the small tubes of the inner and outer glands. He considers a supply of humours essential for the fatty tissue that was thought to ensure the smoothness of the skin and the elasticity of the body. Even sleeplessness could be explained as a result of less lymph being able to penetrate the narrowed nerve tubules. Hutter is not able to offer a physiological explanation of the role of the brain in the reduction of mental functions, but he maintains that mutual interaction of body and mind was a sacred law, best exemplified by the mentally ill. $^{73}$

\section{Part II: Afflictions and Illnesses Associated with Old Age}

Here Hutter continues with a detailed assessment of various illnesses that affect mostly, although not only, old people (such as plethora, haemorrhoids, and cacochymia) and for this reason cannot be associated exclusively with old age. $\mathrm{He}$ concludes this part with the comment that death can be caused by old age alone (mors ex aetatis vitio). As a result of the blood not being purified and a narrowing of the smallest blood vessels, the blood flow becomes weaker and the blood stagnates completely in the intestines and decomposes. This causes a fatal putrefaction of the spleen, which can be seen in a post-mortem.

\section{Part III: Cure}

Hutter continues with a discussion of the treatment of old age. Although the authorities of ancient times had considered it to be an untreatable condition, he claims that experience has shown that life expectancy could be improved by a correct lifestyle. He believes that the first principle is to maintain a free and regular circulatory system in order to protect against illness. Furthermore, secretion and excretion should not be impeded and the production of suitable new humours should be

\footnotetext{
${ }^{71}$ Hutter, op. cit., note 1 above, p. 21. This concept of liquidum nerveum, an ether-like substance, which is produced in the tubuli of the brain and stimulates the extremities through the nerves, can be compared to Galen's spiritus animales; with regard to its mechanical structure and way of functioning it represents an important part of the medical theory of Friedrich Hoffmann; cf. Müller, op. cit., note 69 above, pp. 112-13.
}

\footnotetext{
${ }^{72}$ According to Grmek (op. cit., note 1, p. 77), hardening in the walls of the aorta had been discussed by Galen. Santorio Santorio also describes old age as a general hardening of the fibres in his De medicina statica, see note 59 above.

${ }^{73}$ Hutter, op. cit., note 1 above, $\$ 5-17$, pp. 10-24.
} 


\section{Daniel Schäfer}

stimulated. This could supposedly be achieved by a diet based on the "six nonnaturals" (Sex res non naturales) ${ }^{74}$ and by moderate dosages of various drugs. ${ }^{75}$

This brief description of Hutter's analysis of old age clearly shows the influence of iatromechanics, which was gaining a hold in Germany as a result of the influence of Descartes and Harvey. Hutter's professor, Friedrich Hoffmann, was one of its main supporters, in that he developed a comprehensive physiological and pathological system based on its principles. ${ }^{76}$ His student, in turn, tried to explain old age as a result of a disturbance in the equilibrium between tension and extension, a diminishing of strength and a restriction in the flow of humours. The Galenic theory of a dyscrasia of the humores seems, on the other hand, significantly repressed, as to be expected for this period, and the Aristotelian flame metaphor is not mentioned at all. The role of Hippocrates as an authority for the integrality of the person is now more predominant. ${ }^{77}$ This was a very significant element for Hutter's comprehensive concept of "old age" as an illness.

By radically equating old age with illness, Hutter also seems to reiterate the suggestions of his professor. Hoffmann's Medicina rationalis systematica (1718) analyses the nature and cause of life and (ex negativo) death. Hoffmann does not subscribe to the humoral-pathological definition of death as the onset of putrefaction, but defines it as a mechanical process, involving the stopping of the heart and the circulation, which often causes putrefaction to occur. Terence is also briefly quoted in this context. ${ }^{78}$ Seven years before Hutter, in a thesis on dietetics in old age (1725), which was rather conventional at the time, Friedrich Hoffmann and Moritz Friedrich Nitschius stated that the sapientissimus noster Senex, Hippocrates, had (allegedly) described old age as an illness, ${ }^{79}$ and proposed a systematic nosological concept of old age, explaining it as an unavoidable thickening, hardening and drying out of the solid parts of the body which impedes the flow of blood and humours and therefore the functiones animales, vitales and naturales. His pupil Hutter had only to expand on these considerations.

Apart from Glagau and Hutter, numerous other medical authors of the eighteenth century mentioned the Terence quotation in an aphoristic attempt to describe the alleged desperate state of old age ${ }^{80}$ Some papers even attributed the quotation to

\footnotetext{
${ }^{74}$ See note 69 above. Hutter mentions briefly each of the "non-naturals"; Hutter, op. cit., note 1 above, $\$ 27-33$, pp. 33-40.

${ }^{75}$ Ibid., pp. $40-4$. Most of these remedies had already been recommended by Hoffmann and Nitschius, op. cit., note 79 below.

${ }^{76}$ See Müller, op. cit., note 69 above, pp. 132-3.

${ }^{77}$ Hutter, op. cit., note 1 above, $\S 16$, p. 23.

${ }^{78}$ Friedrich Hoffmann, Opera omnia physicomedica, 6 vols, Geneva, Tournes, 1748, vol. 1, pp. 30-2 (lib. 1 , sect. 1 , cap. 2 ; the Terence quotation is to be found in the preceeding chapter, cap. $1, \S 38)$. See also Müller, op. cit., note 69 above, pp. $70-8$.

${ }^{79}$ Friedrich Hoffmann and Mauritius Fridericus Nitschius, Dissertatio de valetudine senum, Halle an der Saale, 1725, in Hoffmann,
}

op. cit., note 78 , vol. 5 , pp. $289-96$, on p. 289 (§ 2). For Hoffmann's concept of the ageing process, see also Müller, op. cit., note 69, pp. 132-3. Such a statement cannot be proved in the Corpus Hippocraticum, but is widespread in the eighteenth century (see note 81 ). It is possible that Hoffmann's assertion was based on an unclear quotation from Melchior Sebitz (see note 53 above).

${ }^{80}$ See Justus Vesti and Ambrosius Stegmann, Disputatio inauguralis medica de affectibus senum Salomonaeis ... sub praesidio ... Justi Vesti, Erfurt, Kindlebianus, 1692, p. 4; Christian Warlitz, Valetudinarium senum Salomonaeum medico-sacrum, ad Ecclesiastae cap. 12, in quo simul itinerarium sanguinis microcosmicum seu circulus sanguinis, antiquis tectus, detegitur, 


\section{'That Senescence Itself is an Illness'}

Hippocrates (like that of Hoffmann) ${ }^{81}$ while others did not mention any source. ${ }^{82}$ None of these authors attempted to analyse this statement in its medical context. In this, Hutter and Glagau were exceptional, in that they accepted the widely disseminated controversial Phormio quotation in a literal sense and based a physiopathological concept of old age on it. But most other medical university texts on old age from the first half of the eighteenth century did quote Terence and did not refute his statement. Therefore it can be regarded as a common idea, which was both well-known and accepted by specialists, and as a popular belief held by practising physicians until well into the twentieth century. ${ }^{83}$

Although little is known about the practical consequences of this idea for the treatment of old people or how it was assessed by the patients themselves and their relatives, it is still interesting to note that the combination "old and ill" frequently occurred in hospital entry records in early modern times (for example, in Zürich) ${ }^{84}$ On the other hand, a powerful countermovement can be identified in texts on health

Leipzig, Friederich Lanck, 1708, pp. 17-18 (here Johannes Chrysostomus among others is referred to as source); Alberti and Hoffmann, op. cit., note 63 above, p. 3; Johann Friedrich Depré and Hermann Härtel, Dissertatio inauguralis medica, De analogia inter primam et ultimam senectutem, Erfurt, J H Grosch, 1720, $\$ 7,14$, pp. 20, 34; Juch and Kamper, op. cit., note 62 above, p. 20; Johann Heinrich Schulze and Johann Daniel Rohr, De senum diaeta, Halle an der Saale, Jo. Christian Hilliger, 1735, $\S 94$, p. 35; Michael Fridericus Liefmann, Dissertatio inauguralis medica de adynamia artis medicae in senibus, Erfurt, J C Hering, 1737, p. 21; Richard Mead, 'Medica sacra', in idem, The medical works, Edinburgh, Alexander Donaldson and Charles Elliot, 1775, repr. New York, AMS Press, 1978, pp. 442-90, on p. 459 (ch. 6, 'The disease of old age'); Friedrich Christian Juncker and Johannes Heinrich Buihring, Dissertatio inauguralis medica De caussis quibusdam praematurae senectutis praecipuis, Halle an der Saale, Stephan, 1765, § 2 , p. 5; Cornelius Van Diepen, Dissertatio medica inauguralis De senectute morbosa, Leiden, Johan Bos, 1768, § 2, p. 9 (contains reference to Hoffmann; may mean Hutter's dissertation).

${ }^{81}$ Johann Georg Bergen and Joachim Horn, Dissertatio inauguralis medica De venae sectionis usu in senibus, Frankfurt an der Oder, Joh. Christoph. Schwartz, 1726, th. 6, p. 8; Christian Lodberg Friis and Robert Stephan Heinrich, Dissertatio medica de morbis senum secundum Hippocratis Aphor. [X]XXI Sect. 3, Copenhagen, 1739, § 3, p. 10; Andreas Elias Büchner and Gottlieb Ernst Gorn, De plethora senum eiusque rationali therapeutica tractatione per

venaesectionem speciatim suscipienda, Halle an der Saale, Joh. Christian Hendel, 1750, p. 18;
Heinrich Grosser, Fulcrum Hypocraticum senectutis humanae, Würzburg, Franz Ernst Nitribitt, 1770, p. 4. For Hoffmann's attribution to Hippocrates see note 79 above.

${ }^{82}$ Stahl and Michaelis, op. cit., note 63 above, p. 4; Georg Michael Neukum, Dissertatio inauguralis medica De marasmo senili sive marcore naturali, Basel, Academiae Basilensis, Joh. Heinrich Decker, 1743, § 24, p. 15; Johann Christophorus Pohl and Johannes Arnoldus Lebrecht Hagemeyer, De fibra senili, Leipzig, Langenhem, 1746, p. 4; Christian Gottlieb Ludwig, De sanitate senili, [Leipzig], 1759, p. IV; Carolus Linnaeus and Johan Pilgren, 'Senium Salomoneum' (Uppsala, 1759), in Caroli Linnaei Amoenitates academicae, seu Dissertationes variae physicae, medicae, botanicae, antehac seorsim editae, nunc collectae et auctae, Stockholm, Salvius, 1760, vol. 5, pp. 253-72, on pp. 259.

${ }^{83}$ See Lehrbuch der Greisenkrankheiten, ed. Julius Schwalbe, Stuttgart, Ferdinand Enke, 1909, p. VIII. According to Grmek, the Russian biologist, "Elie Metchnikoff did not think that senescence was necessarily a physiological process. In his opinion, it was an accidental disease, which could be checked by preventing intestinal putrefaction"; Grmek, op. cit., note 1 above, p. 12.

${ }^{84}$ The protocol of the Zürich local council of the seventeenth century which records the admission of needy people to the town hospital often contains the combination "alt und übelmögen/kranc/bresthaft" (old and ill); according to an lecture from Aline Steinbrecher, Zürich, 1997. See also the forthcoming thesis of Louise Gray which deals with the definition and use of terms such as "old and worn-out" in the seventeenth-century hospital admissions. 


\section{Daniel Schäfer}

and long life, at first produced by non-medical writers and some marginal members of the medical profession, which had a much more positive approach to old age than that of pathophysiology-based literature. This applies in particular to the famous and influential Discorsi intorno alla vita sobria (1558-63) of the Venetian nobleman and non-medical person, Alvise Cornaro, who used his personal experience to highlight that it is possible to grow old without suffering from any illness. ${ }^{85}$

\section{Eighteenth-Century Changes in Medical Ideas and Education}

If we compare the complex statements from early modern times about the illness "old age", mainly based on Galenism and Aristotelianism, with the outline of the dissertations of the eighteenth century we are confronted with a major question: how could such an about-turn in the medical assessment of old age occur? There are several possible answers to this question.

Such a change took place mainly because of the concept of iatromechanics, based on on the work of Descartes and Harvey, which partly took the place of Galen's explanatory models, and which favoured monocausal theories of illness. Old age could, of course, also have been explained by the comprehensive humoral concept as a cold and dry illness. But this would have differed from Galen's views of the problem. The authority of Galen remained unquestioned in most university chairs until well into the seventeenth century, thereby making it impossible for the idea of an illness "old age" as a medical concept to make any inroads until then.

Perhaps equally important was the fundamental change in the training of medical students. The overall impression given by the eighteenth-century theses is that the authors were not well-informed about the philosophy and, in some cases, the medicine of the ancient and the Islamic worlds. This knowledge had been very much in evidence in earlier papers. ${ }^{86}$ Those wishing to study medicine were still required to complete an unspecified course of basic education, for example, at a Latin school or faculty of arts or philosophy before commencing at a medical faculty. But the lecture timetables of the universities of Freiburg and Heidelberg, for example, do not give any indication of the prescribed books after $1670 .^{87}$ The intense study of the medical authorities was increasingly being replaced by a canon of theoretical and practical subjects, the contents of which were no longer subject to any regulations. The precise study of Aristotle, Hippocrates or Galen was replaced by a (sometimes rather vague) study of some old papers, and more often of contemporary medical literature. In particular, the new theories of a lecturer were accepted eagerly by those doing their doctorate under his supervision. This meant that the ideas about old age

\footnotetext{
${ }^{85}$ Alvise Cornaro, Vom maßvollen Leben oder die Kunst, gesund alt zu werden, edited and introduced by Klaus Bergdolt, Heidelberg, Manutius, 1997.

${ }^{86}$ Osmund Lewry lists, by way of example for the thirteenth to fifteenth century, the number of approximately forty philosophical comments about the Aristotelian Parva naturalia, which deals with the quality and length of life, including
}

works by Albertus Magnus and Petrus Hispanus; Osmund Lewry, 'Study of aging in the Arts Faculty of the universities of Paris and Oxford', in Sheehan (ed.), op. cit., note 30 above, pp. 23-38.

${ }^{87}$ See Hans Böhner, 'Die Geschichte des medizinischen Ausbildungs- und Prüfungswesens in Deutschland von etwa $1240 \mathrm{n}$. Chr. bis heute', Med. thesis, Cologne University, 1962, p. 16. 


\section{'That Senescence Itself is an Illness'}

that originated in ancient times frequently appeared only in selected quotations, often distorted out of all recognition.

Finally, it should be stressed that, at least in the first half of the eighteenth century, the traditional concept of illness as a general process beyond nature (res praeternaturalis) became blurred in the texts. The iatromechanical theory of a progressive hardening of the fibres opened the way for "new" concepts: illness as any malfunction or disruption of the human machine, and illness as a constitutive factor beginning at birth (also in keeping with ancient ideas). This explains the reasoning behind the strange academic debate organized in Paris around 1750 on the topic of whether illness was an inherent part of the human condition. ${ }^{88}$

Because the time of Jakob Hutter was characterized by a scholastic rejection of the authorities in favour of new pathological theories and by changing concepts of illness, a monocausal explanation of the complaints suffered by old people was possible. As we have already seen, this had for a short time the result that old age was summarily equated with illness in some academic papers. This development was supported by the adoption of the polemical statements on old age found in ancient literature but not of the serious discussion in ancient medical texts, as was normal until 1650 .

While there was still some variation among the concepts of illness around 1700 , physicians were for the most part agreed on the pathogenesis of death from old age: it was caused by the restriction of the circulation and an impairment in or weakness of the heart. This traditional idea was so widely recognized that it even appeared in the London Bills of Mortality from the seventeenth century, and until well into the nineteenth century in other statistics, which listed old age as one of the most important causes of death (accounting for 5 to 10 per cent of fatalities), along with numerous illnesses. ${ }^{89}$ Although it is not clear from the tables and commentaries whether old age in this context was understood explicitly as an illness, the concept may nevertheless have further penetrated the consciousness of the population at large in this way. The physiopathology of this "illness" at least did not rule out a special death under any circumstances, and Hutter even uses it to introduce his analysis. However, this type of death was no longer regarded as a "natural" fading away of body and spirit, like a flame that burns itself out, but rather as and to

\footnotetext{
${ }^{88}$ Simone Antonio Bringaud and Joannes Nicolaus Millin de la Courveault, Quaestio medica... Estne totus homo a natura morbus?, Paris, Widow Quillau, 1753. Compare also Johann Bernhard von Fischer, Abhandlung von dem hohen Alter des Menschen, den Stufen, Krankheiten desselben, und den Mitteln, zu denselben zu gelangen, transl. and ed. Theodor Thomas Weichardt, Leipzig, Johann Gottfried Müller, 1777, cap. III, § 14, pp. 282-3.

${ }^{89}$ See John Graunt, Natural and political observations ... made upon the Bills of Mortality,
}

London, Roycroft, 1662, fig. 'The table of casualities' after p. 76, reprinted in: The earliest classics, Pioneers of Demography Series, introduction by Peter Laslett, Farnborough, Gregg International, 1973; Hans-Joachim von Kondratowitz, 'Die Medikalisierung des höheren Lebensalters. Kontinuität und Wandlungen vom ausgehenden 18. bis zum frühen 20 . Jahrhundert', in Medizinische Deutungsmacht im sozialen Wandel des 19. und frühen 20. Jahrhunderts, ed. Alfons Labisch and Reinhard Spree, Bonn, Psychiatrie-Verlag, 1989, pp. 207-22, on p. 218. 


\section{Daniel Schäfer}

life brought about by the morphological effect of the illness "old age" alone." Friedrich Hoffmann, therefore, did not mention natural death in an even earlier dissertation of Christian Blüdorn (1715) nor in his other work. ${ }^{91}$ Of course, it had not been clearly established in the eighteenth century whether this concept of death from old age concerned a natural or a pathological process. But in relevant university texts, fragile, extreme old age and feverish marasmus are completely merged with the idea of an "old age marasmus" (marasmus senilis/naturalis), characterized by a slight fever (febris lenta), consumption, soporific state and the painless transition to death, a fusion, which was still rejected in Galenism. ${ }^{92}$

However, during the eighteenth century, which was characterized by radical changes and competing schools, not everyone was in agreement with these concepts of "old age" as an illness and of "non-natural" death simply caused by ageing. Georg Gottlob Richter (1694-1773), who was later to become a professor at Göttingen, in an academic paper of 1736 'About death without illness', used an identical iatromechanical idea of the physiology of senescence (hardening of the fibres, narrowing of the vessels) to conclude that a natural and peaceful death (euthanasia) is possible in old age. Like Hutter and Glagau, he maintained that this process begins in childhood, quoting Seneca: "as we grow, life is also growing away from us". But Richter regards this lifelong transformation of the organism as a natural process inevitably leading to old age, and names (among others) the aforementioned Alvise Cornaro as an example of how one can grow old and die without suffering from illness. ${ }^{93}$

The most important blow to the short-lasting comprehensive concept of "old age" as an illness was the study of the pathology of bodily organs by Giovanni Battista Morgagni (1682-1771) based mainly on post-mortems on old people. Morphological changes in individual organs rather than an illness of the organism as a whole were now increasingly seen as the original "seat and causes of illnesses" (sedes et causae morborum). In 1754, Johann Bernhard von Fischer was already able to list a variety of anatomical changes associated with old age and expressed his scepticism about the pointless discussions of the "ill health" of the person. ${ }^{94}$ And Burkhard Wilhelm Seiler (1779-1843), who was later to become a professor at Wittenberg, stressed at the turn of the nineteenth century that most old people did not die because of the weaknesses of age but rather as a result of some illness. Therefore, the effects of an

\footnotetext{
${ }^{90}$ Correspondingly, Neukum (op. cit., note 82 above) recognized that, according to the traditional definition, a natural death from old age occurred without a preceding illness, while an expanded concept of illness would consider old age itself to be the illness [which led to death from old age].

${ }^{91}$ Friedrich Hoffmann and Christian Blüdorn, 'De generatione mortis in morbis', in Hoffmann, op. cit., note 78 above, vol. 6, pp. 244-50.

${ }^{92}$ See Hoffmann and Nitschius, op. cit., note 79 above, $\S 5$, p. 290; Hutter, op. cit., note 1 above, $\S 23$, p. 30 (marasmus senilis is equivalent to febris hectica when old people are affected);
}

Neukum op. cit., note 82 above, $\S 21$, p. 13; Abraham Saur, Dissertatio medica inauguralis materiam sistens De marasmo senili, oder von dem sich selbst verzehrenden Alter, Königsberg, Reusner, 1744, § 19, p. 14; Pohl and Hagemeyer, op. cit., note 82 above, $\S 9$, pp. 18-19.

${ }^{93}$ Tum quoque crescimus, vita decrescit; Georg Gottlob Richter, 'Prolusio de morte sine morbo', in Opuscula medica, 3 vols, Frankfurt and Leipzig, I G Fleischer, 1781, vol. 3, pp. 1-24, on p. 12 (quotation from Seneca, Epistolae morales 24, 20) and pp. 21-2 (about Cornaro).

${ }^{94}$ Fischer, op. cit., note 88 above, cap. III 12, pp. $280-1$. 
illness that affected the whole body or a part of the body should be regarded as such and not as changes brought about by old age. ${ }^{95}$

The tendency to attribute the changes accompanying old age to individual illnesses or pathological processes is the attitude of the present. However, the search for a universal concept of ageing and its pathophysiological classification continues on a cellular or molecular biological level. ${ }^{96}$ The present-day distinction between agerelated and age-dependent diseases also reflects the old conflict; ${ }^{97}$ if a direct link can be established between illnesses occurring in old age and the actual ageing process, is the illness then not old age itself?

\section{Under the Influence of Tradition and Reality: The Hesitant Emergence of "Geriatrics" in the Eighteenth Century}

This analysis of the medical theses of Hutter, Glagau and some other authors in their historical context demonstrates, by using the example of the interpretation of old age as an illness, the status of these medical university texts between change and continuity. This is made especially evident by the use of ancient sources. In the early eighteenth century they were often quoted, but freely and only adopted in extracts, with the same few quotations frequently recurring. Interestingly, non-medical aphorisms of ancient times (from Terence or Seneca, for example) became more important than medical texts, which no longer reflected the theory of the day. A special position was occupied by short quotations attributed to Hippocrates, who was to become an increasingly important authority in early modern times. Rather than Galen, Hippocrates was considered to have developed a correct explanation of old age. ${ }^{98}$ The quotations presented him as an authority for a vague holistic concept of age and illness during the natural course of life, although the Corpus Hippocraticum does not provide any basis for this unless as the result of misquotation. The scientific value of these quotations was clearly limited, but their rhetorical function was highly important. ${ }^{99}$

Unlike this tradition, the new concept of "old age" as an illness therefore seems to be less concerned overall with innovation than with deconstruction. Apart from iatromechanical physiology, with which it had only a minor connection (basically involving the liberation from Galen's veto), it broke down the Galenic construction of natural old age only in that it expanded on the concept of illness. But no new physiological or pathological arguments were offered to substantiate this modified

\footnotetext{
${ }^{95}$ Burkhard Wilhelm Seiler, Anatomia corporis humani senilis specimen, Erlangen, Hilpertianis, 1799, pp. XVII-XVIII.

${ }^{96}$ This is what the pathologist W Doerr maintains in relation to the former geriatrician R Rössle: "It is indisputable that there is a 'natural' death as a result of consumption (ageing). Such people do not die, they just stop living"; W Doerr, 'Arzt und Tod', in Der Tod in der Dichtung, Philosophie und Kunst, ed. H H Jansen, Darmstadt, Steinkopff, 1978, pp. 1-11, on p. 7 .
}

\footnotetext{
${ }^{97}$ See Ed Friedlander, 'Aging', in Online in Internet: URL: http://www.pathguy.com/lectures/ aging.htm [5/26/02].

${ }^{98}$ See notes $53,63,77$ and 79 above.

${ }^{99}$ Correspondingly, one of the few critics of the eighteenth century (see also note 62) condemns the concept of an illness "old age" as a "cloudy invention" (nugatorium) elaborated expansively by Rhetoribus, because this viewpoint presents old age in a one-sided way as a major deficit (defectu grandi); Stahl and Michaelis, op. cit., note 63 above, $\S 23$, p. 18.
} 


\section{Daniel Schäfer}

theory, apart from the visualization of changes in the small vessels and fibres with the help of the microscope (Marcello Malpighi, Giorgio Baglivi) and certain preparations with wax injections (Frederik Ruysch). The fundamental questions about the nature of life, illness, old age and death had also already been discussed in ancient times and even the rhetorical weapon against the old concept, the Terence quotation, had been known for centuries and could be traced back to antiquity. It is obvious that this could not stand up long to the scrutiny of the medical profession in the eighteenth century.

Continuity is also to be seen in the medical texts, not only in the explicit appeal to ancient times, but also in the traditionally recommended treatments for old age. The influence of Galenic gerocomy, especially with regard to dietetics and the "six non-naturals", was still widespread, although concepts of pathology and of drugs had undergone many changes. With regard to the materia medica, some recommended remedies had been around for centuries. Most medical instructions in university texts rejected the new iatrochemical drugs, especially those of the Paracelsian school, which had played a central role in rejuvenation and in increasing life expectancy. ${ }^{100}$ Medical faculities of the universities only made fun of these drugs for prolonging life, accepting instead the well-established ancient body of thought. Speculative Galenic ideas on the treatment of old age and on ways to extend life were increasingly examined in an critical way, for example, the shunamitism (so called after Abishag of Shunem, I Kings 1:2) still recommended by Ranchin. In this context, Hermippus redivivus, a work by the Westphalian doctor, Johann Heinrich Cohausen, which appeared in numerous languages and editions between 1742 and 1847, also deserves a mention. "With roguish humour", ${ }^{101}$ he suggested that life expectancy could be extended to 115 years by inhaling the breath of young girls. Cohausen used the example of an imaginary teacher in a prestigious school for young girls in ancient times, and treated tradition in a light-hearted, but at the same time, critical way. The satire, often mistakenly interpreted as serious personal conviction, ${ }^{102}$ was directed especially at the credulity of the people of his time who believed that such sensational remedies could really increase life expectancy and improve the quality of life in old age. ${ }^{103}$

In view of the lack of therapeutic innovation and of the pathology-based pessimism surrounding the complete restoration of health, it is not surprising that the theses discussed did not call for any changes in medicine and certainly did not suggest that there should be any "geriatric" specialization in training, research or clinical practice. One can agree unhesitatingly with Peter N Stearns' claim: "Geriatrics was born in the nineteenth century" ${ }^{104}$ The new concept of "old age" as an illness was presented along with the already known spectrum of illnesses common to old age. These had

\footnotetext{
${ }^{100}$ See also Achim Schulz, 'Paracelsus und die künstliche Lebensverlängerung', Med. thesis, University of Göttingen, 1994; Paul Diepgen, Das Elixir, die köstlichste der Arzneien, Ingelheim, C H Boehringer, 1951, pp. 13-36.

${ }^{101}$ Hermann Paal, Johann Heinrich Cohausen (1665-1750), Jena, Gustav Fischer, 1931, p. 49.

${ }^{102}$ For example, Christoph Wilhelm Hufeland, Makrobiotik oder die Kunst, das menschliche
}

Leben zu verlängern, Berlin, Georg Reimer, 1860, pp. 7-8, but also Grmek, op. cit., note 1 above, pp. 44-5, and Joseph T Freeman, 'The history of geriatrics', Annals of Medical History, n.s., 1938, 10: $324-35$, p. 327. 20-3.

${ }^{103}$ See Paal, op. cit., note 101 above, pp. 7-13,

${ }^{104}$ Stearns, Old age in European society, op. cit., note 6 above, p. 81 . 


\section{'That Senescence Itself is an Illness'}

interested doctors up to this point and must mainly have been relevant to the needs of their patients. Although the proposed monocausal explanation shows signs of the emergence of a new pathologic dimension of old age, it was not based on new examinations or post-mortems, which led rather in the direction of pathological anatomy and its particularistic approach to illnesses of organs occurring in old age. The anatomist Burkhard Wilhelm Seiler was one of the first to call for mass screening and comparative observations in the anatomy, pathology and clinical practice of extreme old age, a call which was partly taken up again by French medicine in the early nineteenth century, and by the monographs of Carl Friedrich Canstatt (1839) and Lorenz Geist (1857-60). ${ }^{105}$

However, the stagnation in treatment and clinical observation, which continued in the eighteenth century, contrasts with a gradual change in basic medical concepts. Did the thesis of an illness "old age" become important in this process? It may be interesting from a philosophical point of view even today, but was surely not a productive medical theory. Although it reached an impasse, this argument was nevertheless part of the change which led from the holistic-speculative and systembased approach of Galenism to the modern evidence-based medicine, at first with a pathologic-anatomic basis, and later a clinical and statistical one. Modified concepts of illness, the natural course of life, and death, which are surprisingly interdependent and inextricably linked to the transitional idea of Glagau and Hutter, represent important landmarks in this development process. Along the way, it is possible to distinguish some important steps taken in medicine towards the present-day comprehensive medicalization of human existence (birth, childhood, women, psychological disturbance, lawbreakers, old age, death), which began in earlier centuries, but is clearly identifiable from the eighteenth century onwards. The illness "old age" could be regarded as one of these steps because old age is recognized for the first time by physicians on a theoretical level as a pathological, and as such, an indisputably medical process.

To conclude, this consideration provides an answer to the final question posed at the outset of whether the changed medical concept of old age was the expression of a hostile attitude towards senescence on the part of society in the early eighteenth century: this has to be answered in the negative. Although old age and growing old tended to be regarded as a double-edged sword, both a desirable aim and a dreadful event, it was mainly treated in an unsympathetic way from the time of the Renaissance until well into the seventeenth century. This occurred predominantly in literature and art with a moralizing intention, ${ }^{106}$ and was also influenced by many traditions originating in antiquity. The historian Peter Borscheid suggests, however, on the basis of various sources from social and economic history, literature and philosophy, that a clear revaluation of old age took place after the Thirty Years' War. This was influenced on the one hand by the ideas of tolerance and morality of the Enlightenment

${ }^{105}$ See Grmek, op. cit, note 1 above, pp. 69-72; regarding Canstatt and Geist see note 65 above.

${ }^{106}$ For example in the emblem Non illaudata senectus, which portrays a fish out of water as pictura; see Joachim Camerarius, Symbola et emblemata, 4 vols, Nürnberg, 1590-1604, repr. Graz 1988, vol. 4, p. 27. 


\section{Daniel Schäfer}

and Pietism, and on the other by the emphasis on parental authority in a society whose structure was still very hierarchical. ${ }^{107}$ Borscheid's idea, which is put forward convincingly, opens new ways for a social historical interpretation of the illness "old age". From the time of the Renaissance, senescence was a theme in numerous monographs (gerocomies, tracts, dissertations etc.) and in general medical works. ${ }^{108}$ The complaints, weaknesses and limitations of this stage of life were usually compared to the previous period of life or the healthy body. In this way, old age and what it comprised were per se attributed negative characteristics from a medical point of view. The positive sides of old age, a common theme of the philosophical-rhetorical traditions of Cicero's Cato Maior De senectute, which influenced, in particular, laymen interested in medicine, rarely appeared in medical texts as the alleged effective results of dietetics and therapy, and were usually illustrated by historical examples. ${ }^{109}$ The situation in which old age was regarded in toto as an illness after 1700 could be interpreted as an intensified debasement of old age, ${ }^{110}$ but it was more probably indicative of a revaluation of the last phase of life (this, of course, applied only to the medical field and did not correspond to Terence's negative attitude). ${ }^{111}$ From a theoretical point of view, physicians were now more interested in the topic of old age, which was regarded as an illness and not only as a natural weak constitution. The revaluation of old age in the period of the early Enlightenment may have contributed to old age being generally recognized as a state of neediness. Both society and the individual in a welfare state (a concept which was to become a medical-political goal after 1750) were under an obligation to try to improve this state of illness. ${ }^{112}$

${ }^{107}$ Borscheid, op. cit., note 6 above, pp. 105-291.

${ }^{108}$ Probably the most comprehensive bibliography on this topic up to the present day can be found in John Sinclair, The code of health and longevity, 4 vols, Edinburgh, A Constable, 1807, vol. 2, pp. 185-303; see also Joseph T Freeman, Aging, its history and literature, New York, Human Sciences Press, 1979, pp. 61-78.

${ }^{109}$ See note 93 above. A short paper by Heinrich Stomer in his old age is an exception; Heinrich Stomer von Auerbach, Schutzrede und verteidigung des ehrlichen und löblichen Alters, Welchs von groben unverstendigen unbillich verschmecht und gelestert wird, Wittemberg, Georg Rhau, 1537. At the start, Stromer, like Cicero, highlights the advantages of old age, but continues by turning his attention to the related complaints and illnesses. Anselmi too reviews Cicero, basing his rejection of the Terence quotation on this; Anselmi, op. cit., note 43 above, pp. 546 .

${ }^{110}$ This interpretation is even supported by the frequent quotation of a further non-medical text in the medical sources of early modern times, i.e. Ecclesiastes 12:1-6. Theologians and doctors interpret this intensive succession of metaphors as a pejorative description of old age, which is inevitably destined to end in death. See Daniel Schäfer, "Hebraeorum Hippokrates rei medicae peritissimus fuit”. Über die Rezeption der pseudosalomonischen Metaphern zum Greisenalter (Koh. 12, 1-6) in der frühneuzeitlichen Medizin', Medizinhist. J., 2000, 35: $219-50$.

${ }^{111}$ References to an honourable old age are increasingly found in the gerontological literature of the eighteenth century; see Fischer, op. cit., note 88 above, cap. III, $\S 20$, p. 286; Evaristus Albites, De consequenda, et producenda senectute disquisitio, Rome, Philippo Neri, 1790, p. 5.

${ }^{112}$ See Reiner Glauer, 'Gesundheitserziehung durch Ärzte als naturrechtlich begründetes Programm aufgeklärter Medizin im 18. Jahrhundert', Med. dentistry thesis, Hanover Medical School, 1976, pp. 11-12. 